\title{
PENGARUH PEMBIAYAAN JUAL BELI TERHADAP KINERJA KEUANGAN PADA BANK SYARIAH MANDIRI PERIODE 2015-2018 DELLA MELITA
}

\author{
Della Melita ${ }^{1}$, Wagiyo ${ }^{2}$ \\ ${ }^{12}$ Fakultas Ekonomi dan Bisnis Universitas Muhammadiyah Pringsewu \\ Email : dellamelita@gmail.com
}

\begin{abstract}
Abstrak
Kinerja keuangan merupakan salah satu indikator keberhasilan atas kesehatan suatu bank. Salah satu indikator untuk menilai kinerja keuangan suatu bank adalah melihat tingkat profitabilitasnya. Penilaian kinerja keuangan bank salah satunya dapat dilihat dari besarnya profitabilitas dengan menggunakan ukuran Return On Assets (ROA). Masalah dalam penelitian ini adalah laba bersih dan total asset yang dimiliki Bank Syariah Mandiri menunjukkan peningkatan setiap tahunnya. Rumusan masalah penelitian ini adalahApakah ada pengaruh Pembiayaan Jual Beli terhadap Kinerja Keuangan pada Bank Syariah Mandiri?. Tujuan penelitian ini adalahuntuk mengetahui pengaruh Pembiayaan Jual Beli terhadap Kinerja Keuangan pada Bank Syariah Mandiri.

Dalam penelitian ini menggunakan metode deskriptif kuantitatif. Metode pengumpulan data yang digunakan adalah dokumentasi. Populasi dalam penelitian ini adalahlaporan keuangan Bank Syariah Mandiri dari tahun 2015 sampai dengan tahun 2018yang seluruhnya dijadikan sampel. Analisis data yang digunakan dalam penelitian ini adalah ROA dan regresi linier sederhana, dengan pengujian hipotesis dengan uji-t.

Berdasarkan analisis data didapat hasil bahwa ada pengaruh Pembiayaan Jual Beli terhadap Kinerja Keuangan pada Bank Syariah Mandiri, dibuktikan dengan nilai thitung > t-tabel, nilai koefisien determinasi sebesar 93,4\%. Sehingga dapat diartikan bahwa kinerja keuangan pada Bank Syariah Mandiri dipengaruhi sebesar 93,4\% oleh pembiayaan jual belidan sisanya sebesar 6,6\% dijelaskan atau dipengaruhi oleh faktor lain yang tidak diindentifikasi dalam penelitian ini.
\end{abstract}

Kata Kunci: Kinerja Syariah Mandiri.

\section{PENDAHULUAN}

\section{A. Latar Belakang Masalah}

Kinerja keuangan merupakan suatu analisis yang dilakukan untuk melihat sejauh mana suatu perusahaan telah melaksanakan dengan menggunakan aturan-aturan pelaksanaan keuangan secara baik dan benar. Kinerja perusahaan merupakan suatu gambaran tentang kondisi keuangan suatu perusahaan yang dianalisis dengan alat-alat 
analisis keuangan, sehingga dapat diketahui mengenai baik buruknya keadaan keuangan suatu perusahaan yang mencerminkan prestasi kerja dalam periode tertentu. Hal ini sangat penting agar sumber daya digunakan secara optimal dalam menghadapi perubahan lingkungan.

Penilaian kinerja keuangan merupakan salah satu cara yang dapat dilakukan oleh pihak manajemen agar dapat memenuhi kewajibannya terhadap para penyandang dana dan juga untuk mencapai tujuan yang telah ditetapkan oleh perusahaan.Kinerja keuangan merupakan salah satu indikator keberhasilan atas kesehatan suatu bank. Salah satu indikator untuk menilai kinerja keuangan suatu bank adalah melihat tingkat profitabilitasnya. Untuk meningkatkan profitabilitasnya, bank akan berusaha meningkatkan pengumpulan dana dari sumber dana yang tersedia disertai dengan upaya meningkatkan kualitas penyaluran aktiva produktif agar dapat menghasilkan tingkat keuntungan atau kinerja keuangan yang baik.

Penilaian kinerja keuangan bank salah satunya dapat dilihat dari besarnya profitabilitas dengan menggunakan ukuran Return On Assets (ROA). ROA menggambarkan kemampuan perusahaan memperoleh laba melalui semua kemampuan dan sumber daya yang ada. Semakin besar ROA yang dimiliki bank, semakin besar pola tingkat keuntungan yang dicapai serta semakin baik pula posisi bank tersebut dari segi penggunaan asset. Dengan kata lain, ROA dapat menunjukan efisiensi manajemen dalam penggunaan asset untuk mendapatkan keuntungan.

Salah satu bank syariah di Indonesia yaitu Bank Syariah Mandiri. Adapun kinerja Bank Syariah Mandiri selama tahun 2015-2018 dapat dilihat pada tabel sebagai berikut:

Tabel 1

Kinerja Bank Syariah Mandiri dilihat dari ROA (Disajikan dalam Jutaan Rupiah)

\begin{tabular}{|c|c|c|c|c|c|}
\hline No & Tahun & Laba Bersih & Total Asset & ROA & Ket \\
\hline 1 & 2015 & $28,957,500.00$ & $7,575,000,000$ & $3.82 \%$ & - \\
\hline 2 & 2016 & $32,541,400.00$ & $6,752,180,000$ & $4.82 \%$ & Naik \\
\hline 3 & 2017 & $36,516,600.00$ & $10,235,644,000$ & $3.57 \%$ & Turun \\
\hline 4 & 2018 & $60,521,300.00$ & $17,475,441,000$ & $3.46 \%$ & Turun \\
\hline
\end{tabular}

Sumber: BSM Annual Report 2015-2018 
Berdasarkan tabel diatas diketahui bahwa laba bersih dan total asset yang dimiliki Bank Syariah Mandiri menunjukkan peningkatan setiap tahunnya. Pembiayaan merupakan dasar yang harus dimiliki suatu bank dan mempengaruhi bagaimana kinerja suatu bank. Dalam pembiayaan ini diambil produk penyaluran dana di bank syariah yang dikembangkan dalam tiga model yaitu: transaksi pembiayaan yang ditujukan untuk memiliki barang dilakukan dengan prinsip jual beli, transaksi pembiayaan yang ditujukan untuk mendapatkan jasa dilakukan dengan prinsip sewa, dan transaksi pembiayaan yang dilakukan untuk usaha kerja sama yang ditujukan untuk mendapatkan sekaligus barang dan jasa dalam prinsip bagi hasil.

Produk-produk pembiayaan Bank Syariah Mandiri banyak macam disediakan untuk para nasabahnya, misalnya pembiayaan yang diberikan untuk modal kerja, investasi atau keperluan konsumsi. Pembiayaan sendiri ada tiga jenis yaitu pembiayaan jual beli, pembiayaan bagi hasil, dan pembiayaan sewa menyewa. Pada Bank Syariah Mandiri pembiayaan jual beli sendiri ada dengan akad murabahah dan akad istishna dengan keuntungan berupa nisbah bagi hasil. Produk-produk pembiayaan berbasis syariah memiliki karakteristik seperti tidak memungut bunga dalam berbagai bentuk karena riba, menetapkan uang sebagai alat tukar bukan sebagai komoditas yang diperdagangkan.

\section{B. Rumusan Masalah}

Berdasarkan uraian latar belakang di atas, maka rumusan masalah yang dapat diajukan pada penelitian ini adalah sebagai berikut:

Apakah ada pengaruh Pembiayaan Jual Beli terhadapKinerja Keuangan pada Bank Syariah Mandiri?

\section{LANDASAN TEORI}

\section{A. Kinerja Keuangan}

\section{Pengertian Kinerja Keuangan}

Menurut Hanafi (2016: 69) "Kinerja keuangan didefinisikan sebagai performing measurement, yaitu kualifikasi dan efisiensi perusahaan atau segmen atau keefektifan dalam pengoperasian bisnis selama periode akuntansi”. Sedangkan menurut Irhan Fahmi (2015:2) "kinerja keuangan adalah suatu analisis yang dilakukan untuk melihat sejauh mana suatu perusahaan telah melaksanakan dengan menggunakan aturan-aturan pelaksanaan keuangan secara baik dan benar. Kinerja perusahaan merupakan suatu gambaran tentang kondisi keuangan suatu perusahaan yang dianalisis dengan alat-alat analisis keuangan, sehingga dapat diketahui mengenai baik buruknya keadaan keuangan suatu perusahaan yang mencerminkan prestasi kerja dalam periode tertentu. Hal ini sangat penting agar sumber daya digunakan secara optimal dalam menghadapi perubahan lingkungan".

Berdasarkan pendapat ahli di atas dapat disimpulkan bahwa kinerja 
keuangan adalah suatu usaha formal yang dilaksanakan perusahaan untuk mengevaluasi efisien dan efektivitas dari aktivitas perusahaan yang telah dilaksanakan pada periode waktu tertentu.

\section{Jenis Penilaian Kinerja Keuangan}

Menurut Hansen, (2014:

"Perspektif keuangan menetapkan tujuan kinerja jangka pendek dan jangka panjang”. Dalam mengukur perspektif keuangan, manajemen perusahaan dapat menggunakan analisis rasio sebagai alat ukur kinerja keuangan perusahaan. Adapun rasio yang dapat digunakan untuk mengukur kinerja keuangan perusahaan adalah sebagai berikut:

a. Rasio Likuiditas

Rasio likuiditas yaitu rasio yang digunakan untuk mengukur kemampuan perusahaan dalam membayar kewajiban jangka pendeknya dengan menggunakan aset lancar yang dimiliki. Ukuran rasio yang digunakan untuk mengukur rasio likuiditas adalah Current Ratio, Quick Ratio, dan Cash Ratio.

b. Rasio Solvabilitas

Rasio solvabilitas yang disebut juga sebagai rasio leverage mengukur perbandingan dana yang memiliki perusahaan dengan dana yang dipinjam dari kredit perusahaan tersebut. Rasio yang digunakan untuk mengukur rasio solvabilitas yaitu Total Debt to Equity Ratio dan Total Debt to Total Asset Ratio.

c. Rasio Profitabilitas
Rasio profitabilitas yaitu rasio yang digunakan untuk mengukur kemampuan perusahaan dalam memperoleh laba. Ukuran yang dipakai untuk menghitung rasio profitabilitas yaitu Gross Profit Margin, Net Profit Margin, Return On Investment, dan Return on Equity.

d. Rasio Pertumbuhan

Rasio pertumbuhan menghitung besarnya tingkat pertumbuhan perusahaan dalam suatu periode tertentu. Rasio yang digunakan untuk menghitung rasio pertumbuhan adalah rasio laba terhadap saham beredar (EPS), rasio harga saham terhadap laba per lembar saham ( $P / E$ Ratio), rasio harga saham terhadap penjualan $(P / S$ Ratio), dan rasio harga saham terhadap nilai buku (PB/V Ratio).

3. Tujuan Penilaian Kinerja Keuaungan Munawir (2012: 31) menyatakan bahwa tujuan dari pengukuran kinerja keuangan perusahaan adalah :

a. Mengetahui tingkat likuiditas

Likuiditas menunjukkan kemampuan suatu perusahaan untuk memenuhi kewajiban keuangan yang harus segera diselesaikan pada saat ditagih.

b. Mengetahui tingkat solvabilitas Menunjukkan kemampuan perusahaan untuk memenuhi kewajiban keuangannya apabia perusahaan tersebut dilikuidasi, baik keuangna jangja pendek maupun jangka panjang.

c. Mengetahui tingkat rentabilitas 
Rentabilitas atau yang sering disebut dengan profitabilitas menunjukkan kemampuan perusahaan untuk menghasilkan laba selama periode tertentu.

d. Mengetahui tingkat stabilitas Menunjukkan kemampuan perusahaan untuk melakukan usahanya dengan stabil, yang diukur dengan mempertimbangkan kemampuan perusahaan untuk membayar hutang-hutangnya serta membayar beban bunga atas hutang-hutangnya tepat pada waktunya.

\section{Indikator Kinerja Keuangan}

Dalam mengukur perspektif keuangan, manajemen perusahaan dapat menggunakan analisis rasio sebagai alat ukur kinerja keuangan perusahaan. Perspektif keuangan mengacu pada konsekuensi keuangan secara keseluruhan dari perspektif lainnya.

Menurut Hansen, (2014: 76) Adapun rasio yang dapat digunakan untuk mengukur kinerja keuangan perusahaan adalah sebagai berikut:

a. Rasio Likuiditas

Rasio likuiditas yaitu rasio yang digunakan untuk mengukur kemampuan perusahaan dalam membayar kewajiban jangka pendeknya dengan menggunakan aset lancar yang dimiliki. Ukuran rasio yang digunakan untuk mengukur rasio likuiditas adalah Current Ratio, Quick Ratio, dan Cash Ratio, umus yang digunakan

1) CurrentRatio = $\frac{\text { CurrentAsset }}{\text { CurrentLiabilities }} \times 100 \%$
2) Quick Ratio =

$$
\frac{\text { Inventories }}{\text { CurrentDebt }} \times 100 \%
$$

3) Cash Ratio = $\frac{\text { Inventories }}{\text { CurrentDebt }} \times 100 \%$

b. Rasio Solvabilitas

Rasio solvabilitas yang disebut juga sebagai rasio leverage mengukur perbandingan dana yang memiliki perusahaan dengan dana yang dipinjam dari kredit perusahaan tersebut. Rasio yang digunakan untuk mengukur rasio solvabilitas yaitu Total Debt to Equity Ratio dan Total Debt to Total Asset Ratio, dengan rumus :

1) Total Debt to Equity Ratio = $\frac{\text { TotalUtang }}{\text { TotalShareholder'sE quity }} \times 100 \%$

2) Total Debt to Total Asset Ratio $=\frac{\text { TotalUtang }}{\text { Modal }} \times 100 \%$

c. Rasio Profitabilitas

Rasio profitabilitas yaitu rasio yang digunakan untuk mengukur kemampuan perusahaan dalam memperoleh laba. Ukuran yang dipakai untuk menghitung rasio profitabilitas yaitu Gross Profit Margin, Net Profit Margin, Return On Investment, dan Return on Equity, dengan rumus:

1) Gross Profit Margin = $\frac{\text { GrossProfit }}{\text { Netsales }} \times 100 \%$

2) Net Profit Margin= $\frac{\text { NetProfit }}{\text { Netsales }} \times 100 \%$

3) Return On Investment = $\frac{\text { EAT }}{\text { TotalAssets }} \times 100 \%$ 


\section{4) Return On Equity = $\frac{\text { EAT }}{\text { Equity }} \times 100 \%$}

d. Rasio Pertumbuhan

Rasio pertumbuhan menghitung besarnya tingkat pertumbuhan perusahaan dalam suatu periode tertentu. Rasio yang digunakan untuk menghitung rasio pertumbuhan adalah rasio laba terhadap saham beredar (EPS), rasio harga saham terhadap laba per lembar saham ( $P / E$ Ratio), rasio harga saham terhadap penjualan ( $P / S$ Ratio), dan rasio harga saham terhadap nilai buku $(P B / V$ Ratio $)$, rumus yang digunakan :

1) Rasio laba terhadap saham beredar $(\mathrm{EPS})=$ $\frac{\text { Keuntungan bersih }}{\text { Jumlah saham beredar }} \times 100 \%$

2) Rasio harga saham terhadap penjualan $(\mathrm{P} / \mathrm{S}$ Ratio $)=$ $\frac{\text { Harga saham }}{\text { Penjualan per lembar saham }} \times 100 \%$

3) Rasio harga saham terhadap nilai buku $(\mathrm{PB} / \mathrm{V}$ Ratio $)=$ $\frac{\text { Harga saham }}{\text { (total harta - total hutang) }} \times 100 \%$

\section{B. Pembiayaan Jual Beli}

\section{Pengertian Pembiayaan}

Menurut M. Syafii Antonio (2016: 17) bahwa "pembiayaan atau financing, yaitu pendanaan yang di berikan oleh suatu pihak kepada pihak lain untuk mendukung investasi yang telah direncanakan, baik dilakukan sendiri maupun lembaga.

Menurut sifat penggunaannya, pembiayaan dapat dibagi menjadi dua hal berikut: a. Pembiayaan Produktif, yaitu pembiayaan yang ditunjukan untuk memenuhi kebutuhan produksi dalam arti luas, yaitu peningkatan usaha, baik usaha produksi, perdagangan, maupun investasi.

b. Pembiayaan Konsumtif, yaitu pembiayaan yang digunakan untuk memenuhi kebutuhan konsumsi, yang akan habis digunakan untuk memenuhi kebutuhan.

\section{Jenis-jenis Pembiayaan}

Sesuai dengan akad pengembangan produk, maka bank syariah memiliki banyak jenis pembiayaan. Menurut M. Syafii Antonio (2016: 22) Jenisjenis pembiayaan pada dasarnya dapat dikelompokan menurut beberapa aspek, diantaranya:

a. Pembiayaan menurut tujuan

Pembiayaan menurut tujuannya dibedakan menjadi:

1) Pembiayaan modal kerja,yaitu pembiayaan yang dimaksudkan untuk mendapatkan modal dalam rangka pengembangan usaha.

2) Pembiayaan investasi, yaitu pembiayaan yang dimaksudkan untuk melakukan investasi atau pengadaan barang konsumtif.

b. Pembiayaan menurut jangka waktu yang dibedakan menjadi:

1) Pembiayaan jangka waktu pendek, pembiayaan yang dilakukan dengan waktu 1 bulan sampai 1 tahun.

2) Pembiayaan jangka waktu menengah, prmbiayaan yang dilakukan dengan waktu 1 tahun sampai 5 tahun 
3) Pembiayaan jangka waktu panjang, pembiayaan yang dilakukan dengan waktu lebih dari 5 tahun.

Jenis pembiayaan pada bank syariah akan diwujudkan dalam bentuk aktiva produktif dan aktiva tidak produktif, yaitu:

a. Jenis aktiva produktif pada bank syariah, dialokasikan dalam bentuk pembiayaan sebagai berikut:

1) Pembiayaan dengan prinsip bagi hasil. Untuk jenis pembiayaan dengan prinsip ini meliputi:

a) Pembiayaan Mudharabah; perjanjian antara penanam dana dan pengelola dana untuk melakukan kegiatan usaha tertentu, dengan pembagian keuntungan antara kedua belah pihak berdasarkan nisbah yang telah disepakati sebelumnya.

b) Pembiayaan Musyarakah; perrjanjian di antara para pemilik dana/modal untuk mencampurkan dana/modal mereka pada suatu usaha tertentu, dengan pembagian keuntungan diantara pemilik dana modal berdasarkan nisbah yang terlah disepakati sebelumnya.

2) Pembiayaan dengan prinsip jual beli (piutang). Untuk jenis pembiayaan dengan prinsip ini meliputi:
a) Pembiayaan
Murabahah;

perjanjian jual-beli antara bank dan nasabah dimana Bank Syariah membeli barang yang diperlukan oleh nasabah dan kemudian menjualnya kepada nasabah yang bersangkutan sebesar harga perolehan ditambah dengan margin/ keuntungan yang disepakati antara Bank Syariah dan nasabah.

b) Pembiayaan Salam; perjanjian jual beli barang dengan cara pemesanan dengan syarat-syarat tertentu dan pembayaran harga terlebih dahulu.

c) Pembiayaan Istishna; perjanjian jual beli dalam bentuk pemesanan pembuatan barang drengan criteria dan persyaratan tertentu yang disepakati antara pemesan dan penjual.

3) Pembiayaan dengan prinsp sewa. Untuk jenis pembiayaan ini diklasifikasikan menjadi pembiayaan:

a) Pembiayaan Ijarah; perjanjian sewa menyewa suatu barang dalam waktu tertentu melalui pembayaran sewa.

b) Pembiayaan Ijarah Muntahiya Biltamlik/Wa Iqtina; perjanjian sewa menyewa suatu barang yang diakhiri dengan perpindahan kepemilikan barang dari pihak yang diberikan sewa kepada pihak penyewa.

b. Jenis aktiva tidak produktif yang berkaitan dengan aktivitas pembiayaan adalah berbentuk pinjaman, yang disebut dengan: Pinjaman Qardh; penyediaan dana dana atau tagihan antara bank syariah dengan pihak peminjam yang mewajibkan pihak peminjam melakukan pembayaran sekaligus 
atau secara cicilan dengan jangka waktu tertentu.

\section{Pembiayaan Pada Bank Syariah}

Berdasarkan prinsip-prinsip yang telah dijelaskan sebelumnya, bank syariah dapat menarik dana pihak ketiga atau masyarakat dalam bentuk:

a. Titipan (wadi"ah) simpanan yang dijamin kemanan dan pengembaliannya tetapi tanpa memperoleh imbalan atau keuntungan.

b. Partisipasi modal berbagi hasil dan berbagi risiko untuk investasi umum di mana bank akan membayar bagian keuntungan secara proposional dengan portofolio yang didanai dengan modal tersebut.

c. Investasi khusus (mudharabah muqayadah) dimana bank bertindak sebagai manajer investasi untuk memperoleh fee.

\section{Indikator Pembiayaan Jual Beli}

Pembiayaan jual beli adalah bentuk penyaluran dana bank syariah yang berupa pembiayaan dengan prinsip jual beli dengan keuntungan bank yang disebut margin. Bentuk-bentuk akad jual beli yang telah dibahas para ulama dalam fiqih muamalah islamiah terbilang sangat banyak. Jumlahnya bisa mencapai belasan jika tidak puluhan. Menurut M. Syafii Antonio (2016: 101) Dari sekian banyak pembiayaan ada tiga jenis jual beli yang telah banyak dikembangkan sebagai sandaran pokok dalam pembiayaan modal kerja dan investasi dalam perbankan syariah, yaitu bai" al-murabahah, bai" as-salam dan bai" al-istishna.

\section{a. Pembiayaan Murabahah}

Para ahli ekonomi dan keuangan Islam pada umumnya tidak menganjurkan penggunaan murabahah tetapi menganjurkan model pembiayaan berdasarkan profit/ loss sharing. Namun ternyata bank-bank justru lebih banyak menggunakan model pembiayaan murabahah dibandingkan model pembiayaan berdasarkan profit/ loss sharing seperti mudharabah dan musyarakah.

\section{b. Pembiayaan Istishna'}

Istishna" juga merupakan jasa pembiayaan dengan mengambil bentuk transaksi jual beli.Istishna" berarti minta dibuatkan/pesan. Akad yang mengandung tuntutan agar tukang/ ahli (shani) membuatkan suatu pesanan dengan ciri-ciri khusus. Dengan demikian istishna"adalah jual beli antara pemesan dan penerima pesanan, dimana spesifikasi dan harga barang disepakati diawal sedangkan pembayaran dilakukan secara bertahap sesuai kesepakatan.

\section{Kerangka Pikir}

Pembiayaan adalah salah satu bentuk aktiva produktif yang ditujukan untuk mencetak keuntungan. Untuk mengukur kemampuan perusahaan menghasilkan keuntungan dapat menggunakan rasio profitabilitas. Kemampuan perusahaan (Bank) 
untuk menghasilkan laba dalam kegiatan operasinya merupakan fokus utama dalam penilaian prestasi perusahaan (analisis fundamental) karena laba perusahaan selain merupakan indikator kemampuan perusahaan memenuhi kewajiban bagi para penyandang dananya juga merupakan elemen dalam penciptaan nilai perusahaan yang menunjukkan prospek perusahaan di masa yang akan datang. Dari sinilah permasalahnnya menyangkut efektifitas manajemen dalam menggunakan total aktiva maupun aktiva bersih seperti yang tercatat dalam neraca. Bentuk paling mudah dari analisis profitabilitas adalah menghubungkan laba bersih (pendapatan bersih) yang dilaporakan terhadap total aktiva di neraca.

Kinerja keuangan merupakan bagian dari kinerja bank secara keseluruhan. Gambaran tentang perkembangan keuangan suatu perusahaan dapat diperoleh dengan menganalisis data keuangan perusahaan yang bersangkutan dan data keuangan itu akan tercermin didalam laporan keuangan. Analisis laporan keuangan mencakup analisis rasio keuangan agar dapat mengetahui kondisi keuangan baik pada waktu yang telah ditelah berlaku, kondisi tahun berjalan maupun prediksi waktu yang akan datang. Perkembangan kualitas bank syariah dapat ditinjau dari kemampuan kinerja bank syariah dan kelangsungan usahanya yang dipengaruhi oleh kualitas penanaman dana atau pembiayaan. Namun dalam penelitian ini, pembiayaan jual beli yang menjadi minat untuk penulis teliti bagaimana pengaruhnya terhadap kinerja keuangan.

Berdasarkan landasan teoritis yang sudah diuraikan penulis, maka kerangka pemikiran dalam penulisan ini digambarkan sebagai berikut:

\section{Gambar 1}

Kerangka Pemikiran

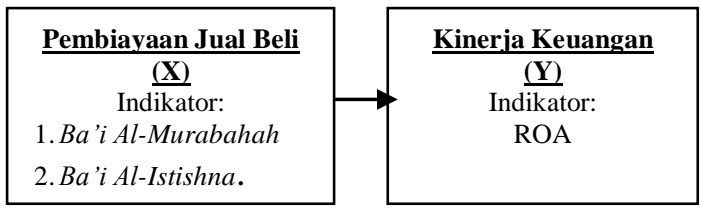

D. Hipotesis

Menurut Arikunto, (2016:110) Hipotesis dapat diartikan sebagai suatu jawaban yang bersifat sementara terhadap permasalahan penelitian, sampai terbukti melalui data yang terkumpul. Sedangkan menurut Sugiyono, (2018:63) Hipotesis merupakan jawaban sementara terhadap rumusan masalah penelitian, dimana rumusan masalah penelitian telah dinyatakan dalam bentuk kalimat pertanyaan.

Berdasarkan kedua pendapat diatas maka peneliti dapat menyimpulkan bahwa hipotesis adalah jawaban sementara atas rumusan masalah penelitian yang masih memerlukan pengujian untuk memperoleh kebenarannya.

Dengan melihat uraian perumusan masalah maka dapat diajukan hipotesis sebagai berikut: 
Ada pengaruh Pembiayaan Jual Beli terhadap Kinerja Keuangan pada Bank Syariah Mandiri.

\section{METODOLOGI PENELITIAN}

\section{A. Metode Penelitian}

Metode penelitian merupakan suatu sistem yang digunakan dalam suatu penelitian sehingga akan dapat memperjelas dan sekaligus membantu dalam memecahkan masalah-masalah yang diteliti. Penelitian ini merupakan penelitian deskriptif, data yang diperoleh dari sampel populasi penelitian dianalisis sesuai dengan metode statistik yang digunakan kemudian diinterprestasikan.

\section{B. Definisi Operasional Variabel Penelitian}

Definisi operasional merupakan suatu penjelasan konsep yang terdapat pada judul penelitian yang dapat diukur jenis dan tingkatannya sehingga variabel-variabel yang diteliti menjadi jelas. Definisi operasional penelitian ini adalah sebagai berikut:

1. Kinerja Keuangan (Y)

Kinerja keuangan adalah suatu usaha formal yang dilaksanakan perusahaan untuk mengevaluasi efisien dan efektivitas dari aktivitas perusahaan yang telah dilaksanakan pada periode waktu tertentu. Indikatornya adalah ROA.

2. Pembiayaan Jual Beli (X)

Pembiayaan jual beli adalah bentuk penyaluran dana bank syariah yang berupa pembiayaan dengan prinsip jual beli dengan keuntungan bank yang disebut margin. Indikatornya adalah bai" al-murabahah, dan bai" alistishna.

Adapun definisi operasional penelitian ini adalah sebagai berikut:

\section{Tabel 2}

Definisi Operasional Variabel

\begin{tabular}{|c|c|c|c|c|}
\hline No & Variabel & Definisi & Indikator & Skala Ukur \\
\hline 1 & $\begin{array}{l}\text { Pembiayaan } \\
\text { jual beli (X) }\end{array}$ & $\begin{array}{lr}\text { Bentuk penyaluran } \\
\text { dana bank } & \text { syariah } \\
\text { yang } & \text { berupa } \\
\text { pembiayaan dengan } \\
\text { prinsip jual beli. } \\
\text { Dengan keuntungan } \\
\text { bank yang disebut } \\
\text { margin }\end{array}$ & $\begin{array}{l}\text { Ba'i Al- } \\
\text { Murabahah, } \\
\text { Ba'i As-Salam, } \\
\text { dan Ba'i Al- } \\
\text { Istishna. }\end{array}$ & Nominal \\
\hline 2 & $\begin{array}{l}\text { Kinerja } \\
\text { keuangan }(\mathrm{Y})\end{array}$ & $\begin{array}{lr}\text { Gambaran } & \text { kondisi } \\
\text { keuangan perusahaan } \\
\text { pada suatu periode } \\
\text { tertentu } \\
\text { menyangkut aspek } \\
\text { penghimpunan dana } \\
\text { maupun penyaluran } \\
\text { dana }\end{array}$ & ROA & Nominal \\
\hline
\end{tabular}




\section{Metode Pengumpulan Data}

Metode pengumpulan data yang digunakan dalam penelitian ini adalah metode dokumentasi. Menurut Sugiyono (2015: 202), "metode dokumentasi adalah menyelidiki benda-benda tertulis seperti bukubuku, majalah, dokumen, peraturanperaturan, notulen rapat dan sebagainya".

Pengumpulan data dengan metode dokumentasi internal dalam penelitian ini adalah data berupa profil Bank Syariah Mandiri, struktur organisasi, sarana dan prasarana, laporan keuangan dan neraca keuangan Bank Syariah Mandiri periode tahun 2015 sampai tahun 2018.

\section{Instrumen Penelitian}

Penelitian ini menggunakan dokumentasi dalam mengumpulkan data. Sehingga instrumen yang digunakan peneliti berupa pedoman dokumentasi antara lain:

1. Dokumentasi Profil Bank Syariah Mandiri (terlampir)

2. Dokumentasi laporan keuangan Bank Syariah Mandiri (terlampir)

3. Dokumentasi neraca keuangan Bank Syariah Mandiri (terlampir)

\section{E. Populasi, Sampel dan Teknik Sampling}

1. Populasi

Menurut Sugiyono (2015: 115), "Populasi adalah wilayah generalisasi terdiri atas obyek/ subyek yang mempunyai kualitas dan karakteristik tertentu. ditetapkan oleh peneliti untuk dipelajari dan kemudian ditarik kesimpulan". Dalam penelitian ini populasinya adalah laporan keuangan Bank Syariah Mandiri selama empat tahun yaitu dari tahun 2015 sampai dengan tahun 2018 .

2. Sampel dan Teknik Sampling

Menurut Sugiyono (2015: 116) "sampel adalah sebagian dari jumlah dan karakteristik yang dimiliki oleh populasi tersebut". Teknik sampling dalam penelitan ini menggunakan teknik non probability sampling dengan menggunakan sampel jenuh atau sampel populasi. Sehingga sampel dalam penelitian ini adalah seluruh laporan keuangan Bank Syariah Mandiri tahun 2015 sampai dengan tahun 2018.

\section{F. Metode Analisis Data}

Penelitian ini bertujuan untuk mengetahui pengaruh pembiayaan jual beli terhadap kinerja keuangan Bank Syariah Mandiri. Adapun metode analisis data yang digunakan dalam penelitian ini adalah sebagai berikut:

1. Analisis Rasio Profitabilitas

Dalam penelitian ini rasio profitabilitas dilihat dari ROI dengan rumus sebagai berikut:

$$
\begin{array}{lll}
\text { Return } & \text { On } & \text { Asset } \\
\frac{\text { TotalAssets }}{\text { Total }} & = & 100 \%
\end{array}
$$

Keterangan:

EAT $=$ Earning After Tax (Laba Bersih setelah pajak)

Total Asset $=$ Aset total yang dimiliki 
2. Analisis Regresi Linier Sederhana Analisis ini digunakan untuk mengetahui arah hubungan antara variabel bebas dengan variabel terikat apakah positif atau negative dan untuk memprediksi nilai dari variabel terikat apabila nilai variabel bebas mengalami fluktuasi. Data yang digunakan biasanya berskala interval atau rasio.

Rumus regresi linier sederhana sebagai berikut:

$$
Y^{\prime}=a+B x
$$

Keterangan:

$$
\begin{aligned}
Y^{\prime}= & \text { Variabel dependen (Pariwisata) } \\
\mathrm{X}= & \text { Variabel independen (Promosi) } \\
\mathrm{a}= & \text { Konstanta (nilai } \mathrm{Y}^{\prime} \text { apabila } \mathrm{X}=0 \text { ) } \\
\mathrm{b}= & \text { Koefisien regresi (nilai peningkatan } \\
& \text { ataupun penurunan) }
\end{aligned}
$$

3. Pengujian Hipotesis

Dalam penelitian ini uji hipotesis menggunakan uji-t. Uji t digunakan untuk menguji hipotesis secara parsial guna menunjukkan pengaruh tiap variabel bebas secara individu terhadap variabel terikat. Uji-t adalah pengujian koefisien regresi masingmasing variabel bebas terhadap variabel terikat untuk mengetahui seberapa besar pengaruh variabel bebas terhadap variabel terikat. Langkah-langkah pengujian dengan menggunakan uji t menurut Sugiyono (2018: 250), sebagai berikut:

a. Menentukan tingkat signifikansi sebesar $\alpha=5 \%$

Tingkat signifikansi $0.05 \%$ atau $5 \%$ artinya kemungkinan besar hasil penarikan kesimpulan memiliki profitabilitas $95 \%$ atau toleransi kesalahan $5 \%$.

b. Menghitung Uji t

$$
\mathrm{t}=\mathrm{r} \frac{\sqrt{n-2}}{\sqrt{1-r^{2}}}
$$

Keterangan:

$\mathrm{t}=\mathrm{t}$ hitung

$\mathrm{r}=$ koefisien korelasi

$\mathrm{n}=$ jumlah data

c. Kriteria Pengambilan keputusan

1) $\mathrm{H}_{0}$ ditolak jika t statistic $<0,05$ atau $t$ hitung $>t$ table

2) $\mathrm{H}_{0}$ diterima jika $\mathrm{t}$ statistic $>$ 0,05 atau $t$ hitung $<\mathrm{t}$ table

Nilai $\mathrm{t}$ tabel didapat dari $\mathrm{df}=\mathrm{n}-\mathrm{k}$ Keterangan :

$\mathrm{n}=$ jumlah observasi

$\mathrm{k}=$ variabel independen

\section{Koefisien Determinasi}

Penggunaan koefisien determinasi ( $R$-Square) pada penelitian ini untuk mengetahui besarnya nilai pengauh pembiayaa jual beli terhadapkinerja keuangan. Rumus yang digunakan untuk mencari nilai koefisien determinasi rumus yang digunakan menurut Sugiyono (2018: 250), yaitu:

$$
\mathrm{KD}=\left(\mathrm{r}_{\mathrm{xy}}\right)^{2} \times 100 \%
$$

Keterangan:

$\mathrm{KD}$ : koefisien determinasi

$\mathrm{r}_{\mathrm{xy}}$ : nilai korelasi variabel bebas dan variabel terikat

\section{HASIL PENELITIAN}

\section{A. Pengumpulan dan Penyajian Data}

\section{Pengumpulan Data}

Penelitian ini menggunakan metode pengumpulan data berupa dokumentasi laporan keuangan dan neraca keuangan Bank Syariah Mandiri periode tahun 2015 sampai tahun 2018 sebagai berikut: 
Tabel 3

Neraca Keuangan Bank Syariah Mandiri periode tahun 2015 sampai tahun 2018 (disajikan dalam jutaan rupiah)

\begin{tabular}{|c|c|r|r|r|r|}
\hline No & & \multicolumn{1}{|c|}{2015} & \multicolumn{1}{c|}{2016} & \multicolumn{1}{c|}{2017} & \multicolumn{1}{c|}{2018} \\
\hline 1 & Total Asset & 70.369 .708 & 78.831 .722 & 87.939 .774 & 98.341 .116 \\
\hline 2 & Total Ekuitas & 5.613 .738 & 6.392 .437 & 7.314 .241 & 8.039 .165 \\
\hline 3 & Dana Syirkah & 54.372 .863 & 60.831 .488 & 66.719 .098 & 75.449 .689 \\
\hline 4 & Total Liabilitas & 9.883 .107 & 11.232 .797 & 13.531 .435 & 14.477 .262 \\
\hline 5 & Laba Bersih & 289.575 & 325.414 & 365.166 & 605.213 \\
\hline
\end{tabular}

Sumber: BSM Annual Report 2015-2018

Berdasarkan neraca keuangan diketahui bahwa nilai asset yang dimiliki oleh Bank Syariah Mandiri dalam 4 tahun terakhir mengalami peningkatan yang cukup signifikan, tercatat pada tahun 2015 nilai asset pada Bank Syariah Mandiri sebanyak Rp 70.369.708.000.000,- dan meningkat pada tahun 2018 menjadi $\mathrm{Rp}$ 98.341.116.000.000,--

Sedangkan laba bersih yang diterima oleh Bank Syariah Mandiri dari tahun 2015 tercatat Rp 289.575.000.000meningkat menjadi $\mathrm{Rp}$ 605.213.000.000,- di tahun 2018 .

\section{Penyajian Data}

1) Pada Penelitian ini data disajikan dalam bentuk angka-angka statistik (kuantitatif) diikuti dengan uraian penjabaran pada tiap angka (tabel).

\section{B. Analisis Data}

1. Analisis Kinerja Keuangan berdasarkan Return Of Asset (ROA) Sebelum melakukan analisis mengenai ROA, terlebih dahulu diketahui jumlah pembiayaan dan pendapatan dari pembiayaan pada Bank Syariah Mandiri tahun 2015 sampai 2018.

a. PembiayaanBank Syariah Mandiri tahun 2015 sampai 2018

Pembiayaan Bank Syariah Mandiri tahun 2015 sampai 2018 disajikan pada tabel sebagai berikut:

Tabel 4

Pembiayaan Bank Syariah Mandiri tahun 2015 sampai 2018

(dalam Jutaan Rupiah)

\begin{tabular}{|c|l|r|r|r|r|}
\hline \multirow{2}{*}{ No } & \multirow{2}{*}{ Pembiayaan } & \multicolumn{4}{|c|}{ Tahun } \\
\cline { 3 - 6 } & & $\mathbf{2 0 1 5}$ & $\mathbf{2 0 1 6}$ & $\mathbf{2 0 1 7}$ & \multicolumn{1}{c|}{$\mathbf{2 0 1 8}$} \\
\hline $\mathbf{1}$ & Jual Beli & & & & \\
\hline & Murabahah & $34,807,005$ & $36,198,342$ & $36,233,737$ & $38,355,135$ \\
\hline & Istinha & 11,593 & 6,042 & 3,144 & 359 \\
\hline & Jumlah & $34,818,598$ & $36,204,384$ & $36,236,881$ & $38,355,494$ \\
\hline $\mathbf{2}$ & Bagi Hasil & & & & \\
\hline & Mudharabah & $2,834,182$ & $3,085,615$ & $3,360,363$ & $3,226,605$ \\
\hline & Musyarakah & $10,277,268$ & $13,001,058$ & $17,268,075$ & $20,622,671$ \\
\hline & Jumlah & $13,111,450$ & $16,086,673$ & $20,628,438$ & $23,849,276$ \\
\hline
\end{tabular}




\begin{tabular}{|c|c|}
\hline 3 & \\
\hline
\end{tabular}

Sumber: BSM Annual Report 2015-2018

Berdasarkan tabel diatas diketahui bahwa jumlah pembiayaan jual beli tahun 2015 sebesar Rp 34,818,598, jumlah pembiayaan jual beli tahun 2016 sebesar Rp 36,204,384, jumlah pembiayaan jual beli tahun 2017 sebesar Rp 36,236,881, dan jumlah pembiayaan jual beli tahun 2018 sebesar Rp 38,355,494.

b. Pendapatandari Pembiayaan Bank Syariah Mandiri tahun 2015 sampai 2018

Pendapatan dari pembiayaan Bank Syariah Mandiri tahun 2015 sampai 2018 disajikan pada tabel sebagai berikut:

Tabel 5

Pembiayaan Bank Syariah Mandiri tahun 2015 sampai 2018 (dalam Jutaan Rupiah)

\begin{tabular}{|c|c|c|c|c|c|}
\hline \multirow[t]{2}{*}{$\mathbf{N}$} & \multirow{2}{*}{$\begin{array}{l}\text { Penda } \\
\text { patan }\end{array}$} & \multicolumn{4}{|c|}{ Tahun } \\
\hline & & 2015 & 2016 & 2017 & 2018 \\
\hline 1 & $\begin{array}{l}\text { Jual } \\
\text { Beli }\end{array}$ & & & & \\
\hline & $\begin{array}{l}\text { Murab } \\
\text { ahah }\end{array}$ & $\begin{array}{r}3,831 \\
, 542 \\
\end{array}$ & $\begin{array}{r}4,048, \\
482\end{array}$ & $\begin{array}{r}4,335 \\
, 905 \\
\end{array}$ & $\begin{array}{r}4,565 \\
, 808 \\
\end{array}$ \\
\hline & Istinha & 1,148 & 83 & 123 & 13 \\
\hline & $\begin{array}{l}\text { Jumla } \\
\mathrm{h} \\
\end{array}$ & $\begin{array}{r}3,832 \\
, 690 \\
\end{array}$ & $\begin{array}{r}4,048, \\
565 \\
\end{array}$ & $\begin{array}{r}4,336 \\
, 028 \\
\end{array}$ & $\begin{array}{r}4,565 \\
, 821 \\
\end{array}$ \\
\hline 2 & $\begin{array}{l}\text { Bagi } \\
\text { Hasil }\end{array}$ & & & & \\
\hline & $\begin{array}{c}\text { Mudh } \\
\text { arabah }\end{array}$ & $\begin{array}{r}364,4 \\
49 \\
\end{array}$ & $\begin{array}{r}362,0 \\
83 \\
\end{array}$ & $\begin{array}{r}363,8 \\
18 \\
\end{array}$ & $\begin{array}{r}330,1 \\
20 \\
\end{array}$ \\
\hline & $\begin{array}{c}\text { Musya } \\
\text { rakah }\end{array}$ & $\begin{array}{r}887,7 \\
59 \\
\end{array}$ & $\begin{array}{r}1,104, \\
685 \\
\end{array}$ & $\begin{array}{r}1,384 \\
, 132 \\
\end{array}$ & $\begin{array}{r}1,616 \\
, 886 \\
\end{array}$ \\
\hline & $\begin{array}{c}\text { Jumla } \\
\mathrm{h}\end{array}$ & $\begin{array}{r}1,252 \\
, 208 \\
\end{array}$ & $\begin{array}{r}1,466 \\
768\end{array}$ & $\begin{array}{r}1,747 \\
, 950 \\
\end{array}$ & $\begin{array}{r}1,947 \\
, 006 \\
\end{array}$ \\
\hline & Total & $\begin{array}{r}5,084 \\
, 898 \\
\end{array}$ & $\begin{array}{r}5,515, \\
333 \\
\end{array}$ & $\begin{array}{r}6,083 \\
, 978 \\
\end{array}$ & $\begin{array}{r}6,512 \\
, 827 \\
\end{array}$ \\
\hline
\end{tabular}

1. Sumber: BSM Annual Report 2015-2018

Berdasarkan tabel diatas diketahui bahwa jumlah pendapatan jual beli tahun 2015 sebesar Rp 3,832,690, jumlah pendapatan jual beli tahun 2016 sebesar Rp 4,048,565, jumlah pendapatan jual beli tahun 2017 sebesar Rp 4,336,028, dan jumlah pendapatan jual beli tahun 2018 sebesar Rp 4,565,821.Selanjutnya untuk mengetahui ROA pada Bank Syariah Mandiri tahun 2015 sampai 2018, dalam penelitian ini dilakukan analisis ROA (Return on Asset) dilihat dari pendapatan dan pembiayaan jual beli pada Bank Syariah Mandiri tahun 2015 sampai 2018.

Hasil perhitungan sebagai berikut:

a. ROA (Return on Asset) Bank Syariah Mandiri tahun 2015

Adapun ROA (Return on Asset) Bank Syariah Mandiri tahun 2015 sebagai berikut:

$$
\begin{aligned}
& \text { ROA }=\frac{3832690}{34818598} \times 100 \% \\
& \text { ROA }=11.00 \%
\end{aligned}
$$

Berdasarkan hasil perhitungan diketahui bahwa nilai ROA Bank Syariah Mandiri dilihat dari pendapatan dan pembiayaan jual beli tahun 2015 sebesar $11,00 \%$, yang berarti kemampuan Bank Syariah Mandiri tahun 2015 dalam memperolah laba berdasarkan pembiayaan jual beli sebesar $11,00 \%$. 
b. ROA (Return on Asset) Bank Syariah Mandiri tahun 2016 Adapun ROA (Return on Asset) Bank Syariah Mandiri tahun 2016 sebagai berikut:

$$
\begin{aligned}
& \mathrm{ROA}=\frac{4048565}{36204384} \times 100 \% \\
& \mathrm{ROA}=11,18 \%
\end{aligned}
$$

Berdasarkan hasil perhitungan diketahui bahwa nilai ROA Bank Syariah Mandiri dilihat dari pendapatan dan pembiayaan jual beli tahun 2016 sebesar 11,18\%, yang berarti kemampuan Bank Syariah Mandiri tahun 2016 dalam memperolah laba berdasarkan pembiayaan jual beli sebesar $11,18 \%$.

c. ROA (Return on Asset) Bank Syariah Mandiri tahun 2017

Adapun ROA (Return on Asset) Bank Syariah Mandiri tahun 2017 sebagai berikut:

$$
\begin{aligned}
& \mathrm{ROA}=\frac{4336028}{36236881} \times 100 \% \\
& \mathrm{ROA}=11,97 \%
\end{aligned}
$$

Berdasarkan hasil perhitungan diketahui bahwa nilai ROA Bank Syariah Mandiri dilihat dari pendapatan dan pembiayaan jual beli tahun 2017 sebesar 11,97\%, yang berarti kemampuan Bank Syariah Mandiri tahun 2017 dalam memperolah laba berdasarkan pembiayaan jual beli sebesar $11,97 \%$.

d. ROA (Return on Asset) Bank Syariah Mandiri tahun 2018

Adapun ROA (Return on Asset) Bank Syariah Mandiri tahun 2018 sebagai berikut:

$$
\begin{aligned}
& \mathrm{ROA}=\frac{4565821}{38355494} \times 100 \% \\
& \mathrm{ROA}=11.90 \%
\end{aligned}
$$

Berdasarkan hasil perhitungan diketahui bahwa nilai ROA Bank Syariah Mandiri dilihat dari pendapatan dan pembiayaan jual beli tahun 2018 sebesar 11,90\%, yang berarti kemampuan Bank Syariah Mandiri tahun 2018 dalam memperolah laba berdasarkan pembiayaan jual beli sebesar $11,90 \%$.

\section{Analisis Regresi Linier Sederhana}

Dalam penelitian ini, karena memiliki satu variabel bebas dan satu variabel terikat, maka alat statistik yang digunakan adalah regresi linear sederhana. Rumus regresi linier sederhana sebagai berikut:

$$
Y^{\prime}=a+B x
$$

\begin{tabular}{|c|c|c|c|c|c|c|}
\hline \multicolumn{7}{|c|}{ Coefficients $^{\mathrm{a}}$} \\
\hline & & \multicolumn{2}{|c|}{$\begin{array}{l}\text { Unstandardized } \\
\text { Coefficients }\end{array}$} & $\begin{array}{c}\text { Standardized } \\
\text { Coefficients }\end{array}$ & & \\
\hline \multicolumn{2}{|c|}{ Model } & $\mathrm{B}$ & Std. Error & Beta & $\mathrm{t}$ & Sig. \\
\hline \multirow{2}{*}{1} & (Constant) & 17.813 & 1.183 & & 15.053 & 0.004 \\
\hline & Pembiayaan Jual Beli & 0.094 & 0.018 & 0.967 & 5.334 & 0.033 \\
\hline & ndent Variable: ROA & & & & & \\
\hline
\end{tabular}

Adapun hasil analisis regresi linier sederhana menggunakan bantuan program SPSS dapat dilihat pada tabel berikut:

Tabel 6.

Hasil Analisis Regresi Linier Sederhana

Sumber: Data Primer diolah dari Lampiran SPSS 
Berdasarkan hasil penghitungan regresi linier sederhana, diperoleh persamaan sebagai berikut:

$$
\mathrm{Y}=17.813+0.094 \mathrm{x}
$$

\section{Keterangan:}

$\mathrm{Y}=17.813$ (Nilai constant variabel terikat) $\mathrm{X}=0.094$ (Nilai koefisien variabel bebas)

Dari hasil persamaan regresi diatas diketahui bahwanilai konstanta kinerja keuangansebesar 17.813, sedangkan nilai koefisien regresi variabel pembiayaan jual beli adalah 0.094, yang artinya apabila pembiayaan jual beli meningkat satu satuan, maka akan meningkatkan kinerja keuangan sebesar 0.094 . Dengan arti lain bahwa Pembiayaan Jual Beli mampu memberikan pengaruh terhadap Kinerja Keuangan pada Bank Syariah Mandiri.

\section{Analisis Hipotesis}

Pengujian tingkat signifikansi koefisien regresi sederhana menggunakan uji $t$ yang dimaksudkan untuk menguji pengaruh Pembiayaan Jual Beli terhadap Kinerja Keuangan pada Bank Syariah Mandiri pada tingkat kepercayaan $95 \%$ atau alpha sebesar 0,05 dengan derajat kebebasan (dk) $=\mathrm{n}-2=2$. Adapun uji $\mathrm{t}$ dari perhitungan menggunakan program SPSS didapat hasil sebagai berikut:

Tabel 6.

Hasil uji t

\begin{tabular}{|c|c|c|}
\hline t-hitung & $\begin{array}{c}\text { t- } \\
\text { tabel }\end{array}$ & Keterangan \\
\hline 5.334 & 2.919 & Signifikan \\
\hline
\end{tabular}

Sumber: Data Primer diolah dari Lampiran SPSS
Berdasarkan hasil penghitungan menggunakan alat bantu SPSS, didapat nilai t-hitung pembiayaan jual beli sebesar 5.334 dan nilai ttabel sebesar 2,919 (nilai t-tabel untuk dk-2 = 2). Hal tersebut dapat diartikan bahwa nilai t-hitung $>$ nilai t-tabel, sehingga $\mathrm{H}_{a}$ diterima dan $\mathrm{H}_{0}$ ditolak, yang berarti ada pengaruh Pembiayaan Jual Beli terhadap Kinerja Keuangan pada Bank Syariah Mandiri.

\section{Koefisien Determinasi}

Pengujian koefisien determinasi $(R$ Square) ditujukan untuk melihat apakah variabel kinerja keuangan dapat dipengaruhi oleh variabel pembiayaan jual beli. Dengan kata lain, penggunaan koefisien determinasi untuk mengetahui kontribusi variabel Pembiayaan Jual Beli terhadap Kinerja Keuangan. Hasil penghitungan koefisien determinasi menggunakan alat bantu SPSS sebagai berikut:

\section{Tabel 7}

Koefisien Determinasi

\begin{tabular}{|l|c|c|c|c|}
\hline \multicolumn{5}{|c|}{ Model Summary } \\
\hline Model & $\mathrm{R}$ & $\begin{array}{c}\mathrm{R} \\
\text { Square }\end{array}$ & $\begin{array}{c}\text { Adjusted } \\
\text { R Square }\end{array}$ & $\begin{array}{c}\text { Std. Error } \\
\text { of the } \\
\text { Estimate }\end{array}$ \\
\hline 1 & $0.967^{\mathrm{a}}$ & 0.934 & 0.901 & .15404 \\
\hline \multicolumn{5}{|c|}{ a. Predictors: (Constant), Pembiayaan Jual Beli } \\
\hline
\end{tabular}

Sumber: Data Primer diolah dari Lampiran SPSS

Rumus yang digunakan untuk mencari nilai koefisien determinasi menurut Sugiyono (2018: 199) adalah sebagai berikut:

$$
\begin{aligned}
& \mathrm{KD}=(r x y)^{2} \times 100 \% \\
& \mathrm{KD}=(0.967)^{2} \times 100 \% \\
& \mathrm{KD}=0,934 \times 100 \%=93,4 \% .
\end{aligned}
$$


Hasil koefisien determinasi didapat nilai sebesar 93,4\%. Sehingga dapat diartikan bahwa kinerja keuangan pada Bank Syariah Mandiri dipengaruhisebesar $93,4 \%$ oleh pembiayaan jual beli. Dengan kata lain, pembiayaan jual beli memberikan kontribusi sebesar 93,4\% terhadap kinerja keuangan dan sisanya sebesar $6,6 \%$ dijelaskan atau dipengaruhi oleh faktor lain yang tidak diindentifikasi dalam penelitian ini. Nilai koefisien determinasi masuk dalam kategori sangat kuat, hal tersebut karena berada dalam interval 0,800-1,000, dapat dilihat pada tabel sebagai berikut:

Tabel 8

Interval Koefisien

\begin{tabular}{|c|c|c|}
\hline No & Nilai Interval & Kategori \\
\hline 1 & $0,800-1,000$ & Sangat Kuat \\
\hline 2 & $0,600-0,800$ & Kuat \\
\hline 3 & $0,400-0,600$ & Cukup Kuat \\
\hline 4 & $0,200-0,400$ & Lemah \\
\hline 5 & $0,000-0,200$ & Sangat Lemah \\
\hline
\end{tabular}

\section{A. Pembahasan Hasil Penelitian}

Tujuan dari penelitian ini ingin mengetahui pengaruh Pembiayaan Jual Beli terhadap Kinerja Keuangan pada Bank Syariah Mandiri. Berdasarkan hasil analisis diperoleh hasil bahwa ada pengaruh Pembiayaan Jual Beli terhadap Kinerja Keuangan pada Bank Syariah Mandiri.

Nilai ROA Bank Syariah Mandiri dilihat dari pendapatan dan pembiayaan jual beli tahun 2015 sebesar $11,00 \%$. Nilai ROA Bank Syariah Mandiri dilihat dari pendapatan dan pembiayaan jual beli tahun 2016 sebesar 11,18\%. Nilai ROA Bank Syariah Mandiri dilihat dari pendapatan dan pembiayaan jual beli tahun 2017 sebesar $11,97 \%$. Nilai ROA Bank Syariah Mandiri dilihat dari pendapatan dan pembiayaan jual beli tahun 2018 sebesar 11,90\% .

Nilai t-hitung pembiayaan jual beli sebesar 5.334 dan nilai t-tabel sebesar 2,919 (nilai t-tabel untuk dk$2=2$ ). Hal tersebut dapat diartikan bahwa nilai t-hitung > nilai t-tabel, sehingga $\mathrm{H}_{\mathrm{a}}$ diterima dan $\mathrm{H}_{0}$ ditolak, yang berarti ada pengaruh Pembiayaan Jual Beli terhadap Kinerja Keuangan pada Bank Syariah Mandiri. Koefisien determinasi didapat nilai sebesar 93,4\%. Sehingga dapat diartikan bahwa kinerja keuangan pada Bank Syariah Mandiri dipengaruhi sebesar 93,4\% oleh pembiayaan jual beli. Dengan kata lain, pembiayaan jual beli memberikan kontribusi sebesar 93,4\% terhadap kinerja keuangan dan sisanya sebesar $6,6 \%$ dijelaskan atau dipengaruhi oleh faktor lain yang tidak diindentifikasi dalam penelitian ini. Nilai koefisien determinasi masuk dalam kategori sangat kuat, hal tersebut karena berada dalam interval 0,800-1,000.

\section{KESIMPULAN}

Berdasarkan analisis data dan pembahasan yang penulis lakukan pada bab sebelumnya, dapat penulis simpulkan sebagai berikut: 
1. Ada pengaruh Pembiayaan Jual Beli terhadap Kinerja Keuangan pada Bank Syariah Mandiri, dibuktikan dengan nilai t-hitung $>$ t-tabel.

2. Nilai Koefisien determinasi sebesar 93,4\%. Sehingga dapat diartikan bahwa kinerja keuangan pada Bank Syariah Mandiri dipengaruhi sebesar 93,4\% oleh pembiayaan jual belidan sisanya sebesar $6,6 \%$ dijelaskan atau dipengaruhi oleh faktor lain yang tidak diindentifikasi dalam penelitian ini.

\section{DAFTAR PUSTAKA}

Arikunto, Suharsimi. 2016. Prosedur

Penelitian Suatu Pendekatan Praktek. Jakarta: Rineka Cipta.

BSM Annual Report 2015. http://www.syariahmandiri.co.id/ wp-content/uploads/

BSM Annual Report 2016. http://www.syariahmandiri.co.id/ wp-content/uploads/

BSM Annual Report 2017. http://www.syariahmandiri.co.id/ wp-content/uploads/

BSM Annual Report 2018. http://www.syariahmandiri.co.id/ wp-content/uploads/

Hanafi. 2016. Manajemen Keuangan. Yogyakarta: BPFE.

Hansen. 2017. Accounting Managerial, $8^{\text {th }}$ ed. Jakarta: Salemba Empat.
Irhan Fahmi. 2015. Manajemen Keuangan Perusahaan dan Pasar Modal. Jakarta: Mitra Wacana Media.

-------.2015. Manajemen Produksi dan Operasi. Bandung: Alfabeta.

M. Syafii Antonio. 2016. Bank Syariah dari Teori ke Praktik. Jakarta: Gema Insani.

Munawir. 2016. Analisa Keuangan. Yogyakarta: Liberty Yogyakarta.

Sugiyono. 2015. Metode Penelitian Bisnis. Bandung: Alfa Beta.

Sugiyono. 2018. Metode Penelitian Kuantitatif dan Kualitatif $R \& D$. Bandung: Alfa Beta.

Tim Penyusun. 2020. Panduan Penulisan Skripsi FEB Universitas Muhammadiyah Pringsewu Lampung. FEB Universitas Muhammadiyah Pringsewu: Lampung.

Undang-Undang No 21 Tahun 2008 Pasal 19 Ayat 1 Tentang Perbankan Syariah, Jakarta: Sinar Grafika. 